\title{
Alpine parks between yesterday and tomorrow - a conceptual history of Alpine na- tional parks via tourism in charismatic parks in Austria, Germany and Switzerland
}

\author{
Christina Pichler-Koban \& Michael Jungmeier
}

Keywords: Alps, conservation history, eco-tourism, parks, protected areas

\section{Abstract}

The history of national parks in Austria, Germany and Switzerland reaches back to the late $19^{\text {th }}$ century. Based on a historic content analysis (ATLAS.ti), this study investigates the different conservation concepts through the example of tourism in charismatic parks in the Alps, such as Swiss National Park, Berchtesgaden National Park and Hohe Tauern National Park. A conception is considered a particular co-occurrence of protagonists, perceived threats, desired conservation goals and instruments applied. Analysing these co-occurrences sheds light on relations between historic milestones in nature conservation and the broader context of debates, changes and developments in society. Such an analysis reveals recurring archetypical conservation narratives and, in the context of tourism, allows identifying six different conceptions to better compare and understand the developments these parks have gone through: 1) fundamental antagonism, 2) selective antagonism, 3) opportunistic co-operation, 4) opportunistic appropriation, 5) co-operative development, and 6) integrative development. The parks' histories differ greatly, but nowadays the conception of integrative development appears to be generally acknowledged.

\section{Introduction}

Protected areas as mirrors and displays of society

Following the definition of the World Conservation Union a protected area is "a clearly defined geographical space, recognised, dedicated and managed, through legal or other effective means, to achieve the long-term conservation of nature with associated ecosystem services and cultural values" (IUCN 2013). However, there are many ways of protecting nature, since the idea of conservation is based on diverse perceptions, notions and imaginations of what is understood by nature. Whenever conservation is object to detailed analysis, a conglomerate of ideologically, scientifically and culturally determined fragments becomes visible. Throughout the history of conservation, its value base has integrated and accumulated different dynamically changing positions, some of which have been contradictory in themselves (Flint et al. 2013).

Any conservation concept includes intrinsic conflicts. This paper draws on changes of conservationists' selected positions during the development of charismatic parks in the Alps to exemplify the complex conceptual roots of nature conservation and to reveal the conceptions, narratives and discourses at work in this context. The conceptual interactions between conservation and tourism presented in the article were identified in a large-scale study on the historic development of Alpine parks (Pichler-Koban \& Jungmeier 2015).

\section{Exploring the history of conservation}

Mainly triggered by prominent anniversaries (2009: Centenary of national parks in Europe; 2014: Centenary of Österreichischer Naturschutzbund (Austrian League for Nature Conservation); 2014: Centenary of Swiss National Park, etc.) the conservation movement has increasingly reflected on its history. These activities usually include a documentation of the institutional development, some biographical notes and references to major achievements of the relevant institutions (e.g. EUROPARC Federation 2009). Few of the historic analyses in recent years met with more public attention than the radical monograph Conservation Refugees - The Hundred-Year Conflict between Global Conservation and Native Peoples (Dowie 2009), since Dowie raised fundamental questions that challenged the self-perception of conservationism. Very plausibly Dowie argues that representatives of conservation have become powerful players on a global scale and need to act in a thoughtful and responsible manner.

Neither the long-term history of conservation nor the historic research on the topic can be sketched in this article. A sample of selected milestones as presented in Table 1 must suffice as a general frame for the individual developments of the parks.

In the German speaking countries, the history of selected conservation institutions has been subject to scientific research. For instance, Farkas (2013), Gepp (2013), Kupper and Schär (2015), and others studied the history of different conservation NGOs, natural sciences associations and Alpine institutions (e.g. Österreichischer Alpenverein 1989; Pichler-Koban 2013; Pichler-Koban \& Jungmeier 2016). In Germany research on conservation history has focused on use and misuse in the interrelations between national and conservationists' movements (e. g. Brüggemeier \& Engels 2005; Franke \& Pfenning 2014; Radkau \& Uekötter 2003; Schmoll 2004; Uekötter 2004). Recently scholarly interest has shifted to international developments and to the question of how to identify and analyse the connections between local and global trends (e. g. Gissibl et al. 2012; Job et al. 2013; Wöbse 2012). 
Table 1 - Selected milestones in conservation and tourism. Socio-historic context for the development of Alpine parks. (Pichler-Koban \& Jungmeier 2015, adapted).

\begin{tabular}{|c|c|}
\hline Year & Milestone / occurrence / development \\
\hline 1827 & Monograph Birds of America by John James Audubon published \\
\hline 1859 & Publication of On the origin of species by Charles Darwin \\
\hline 1864 & Creation of Yosemite Park \\
\hline 1872 & Establishment of Yellowstone National Park \\
\hline 1888 & National Geographic Society founded \\
\hline 1889 & British Royal Society for the Protection of Birds (RSPB) founded \\
\hline 1908 & First proposal for the protection of the Triglav massif \\
\hline 1909 & First national parks in Europe (Sweden) \\
\hline 1914 & Establishment of the Swiss National Park \\
\hline 1922 & Establishment of Gran Paradiso National Park in Italy \\
\hline 1948 & IUPN, today World Conservation Union IUCN, founded \\
\hline 1952 & International Commission for the Protection of the Alps (CIPRA) founded \\
\hline 1958 & Establishment of the World Commision on Protected Areas \\
\hline 1960 & Oscar for the documentary Serengeti shall not die by Bernhard Grzimek \\
\hline 1961 & WWF, today Worldwide Fund for Nature, founded \\
\hline 1962 & Publication of Silent Spring by Rachel Carson \\
\hline 1969 & First World Parks Congress under the auspicies of US president Kennedy \\
\hline 1965 & European diploma for sites of European importance \\
\hline 1969 & IUCN's international classification of protected area categories \\
\hline 1970 & European Year of Conservation launched by the Council of Europe \\
\hline 1970 & Launch of UNESCO's programme Man and the Biosphere \\
\hline 1971 & Convention on Wetlands as first intergovernmental treaty for conservation \\
\hline 1972 & Publication of The Limits to Growth by Dennis Meadows \\
\hline 1972 & Launch of United Nations' Environmental Programme (UNEP) \\
\hline 1972 & UNESCO Convention on World Heritage \\
\hline 1973 & Establishment of Ecrins National Park (France) \\
\hline 1973 & Europarc, Federation of European Protected Areas, founded \\
\hline 1975 & Publication of Die Landschaftsfresser by Jost Krippendorf \\
\hline 1978 & Establishment of Berchtesgaden National Park \\
\hline 1979 & European Directive for Conservation of Wild Birds \\
\hline 1981 & Establishment of Hohe Tauern National Park in Carinthia \\
\hline 1991 & Signing of the Alpine Convention in Salzburg \\
\hline 1992 & Earth Summit in Rio, promoting concepts of sustainable development \\
\hline 1992 & European Directive for Conservation of Natural Habitats/Fauna / Flora \\
\hline 1993 & Convention on Biodiversity \\
\hline 1995 & Publication of Loving them to Death by Europarc Federation \\
\hline 1995 & Alparc, Network of Alpine Protected Areas, founded \\
\hline 2002 & European Charter for Sustainable Tourism \\
\hline 2014 & The Promise of Sidney as outcome of IUCN's Worldparks Congress \\
\hline 2017 & UNWTO declares Year of Sustainable Tourism for Development \\
\hline
\end{tabular}

Individual studies have investigated in detail the history of selected parks, such as Swiss National Park (NP) (Kupper 2012a, b) or Hohe Tauern NP (Kupper \& Wöbse 2013; Kupper et al. 2014). Pichler-Koban and Jungmeier (2015) provide a comparison of developments in Austria (Hohe Tauern NP, Dobratsch Nature Park), Germany (Berchtesgaden NP, Schorfheide Chorin Biosphere Reserve) and Switzerland (Swiss NP, national park candidate Parc Adula). The selection of parks followed an expert-discussion and took into account language (only German-speaking regions), representativity and also practical aspects (such as access to materials and organizations). In this paper the authors only refer to parks of IUCN categories I and II (wilderness areas and NPs) to work with comparable objects of research.
A wide range of studies concerning nature-based tourism (e. g. Hammer et al. 2012; Hammer \& Siegrist 2008; Knaus 2012; Siegrist \& Stremlow 2009; Siegrist et al. 2015) indicates that there is a strong connection between tourism issues and protected areas. This article wants to shed a light on the historical aspects of this long-term relationship.

\section{Research approach and methods}

\section{Terminology and research questions}

The authors use the term charismatic in order to depict parks with an unchallenged national and international reputation. Even if established and recognized later, the territories of these parks have been subject to paradigmatic discussions about conservation all throughout the $20^{\text {th }}$ century. In economic terms, a charismatic park is taken as a unique brand with an image well connected to national identity.

A conception of nature conservation is a particular approach towards conservation that 1) is rooted in a particular notion of nature, 2) is developed and promoted by particular actors embedded in their specific societal and historic context, 3) refers to threats to nature as perceived by these actors and 4) develops, promotes and uses specific instruments and measures to protect nature (Pichler-Koban \& Jungmeier 2015).

Based on a literature review and the qualitative analysis of text excerpts (contemporary documents, interviews) referring to charismatic NPs in the German-speaking regions of the Alps (Berchtesgaden, Hohe Tauern, Swiss, see Figure 1), this paper wants to analyse the interaction between the conservation movement and tourism from the beginning of the $20^{\text {th }}$ century until today: How can the changing relations be described conceptually and what conclusions for the management of parks can be drawn from the findings, both on a theoretical and technical level? Even though the roots of tourism in these regions may date back much further, the discussion about parks in Europe did not begin before 1900 . In this respect the $20^{\text {th }}$ century is decisive for the development of parks.

From a theoretical perspective protected areas result from a concept of modernity (Langer 1991). Nowadays the concept is challenged by fundamental transformations deriving from "rapid globalization of social life" as described by Giddens and Sutton (2013) and increasingly respond and need to respond to an "era of global-local change" (Becken \& Job 2014).

\section{Context and methods applied}

The study is mainly based on empirical data. Eighteen qualitative interviews with contemporary witnesses, actors and researchers were conducted in Austria, Germany and Switzerland in 2013 and 2014 (oral history). The key criterion for the selection of interviewees was their familiarity with and their deep knowledge of the study sites. The interviews helped to focus on issues perceived as most relevant. Written 


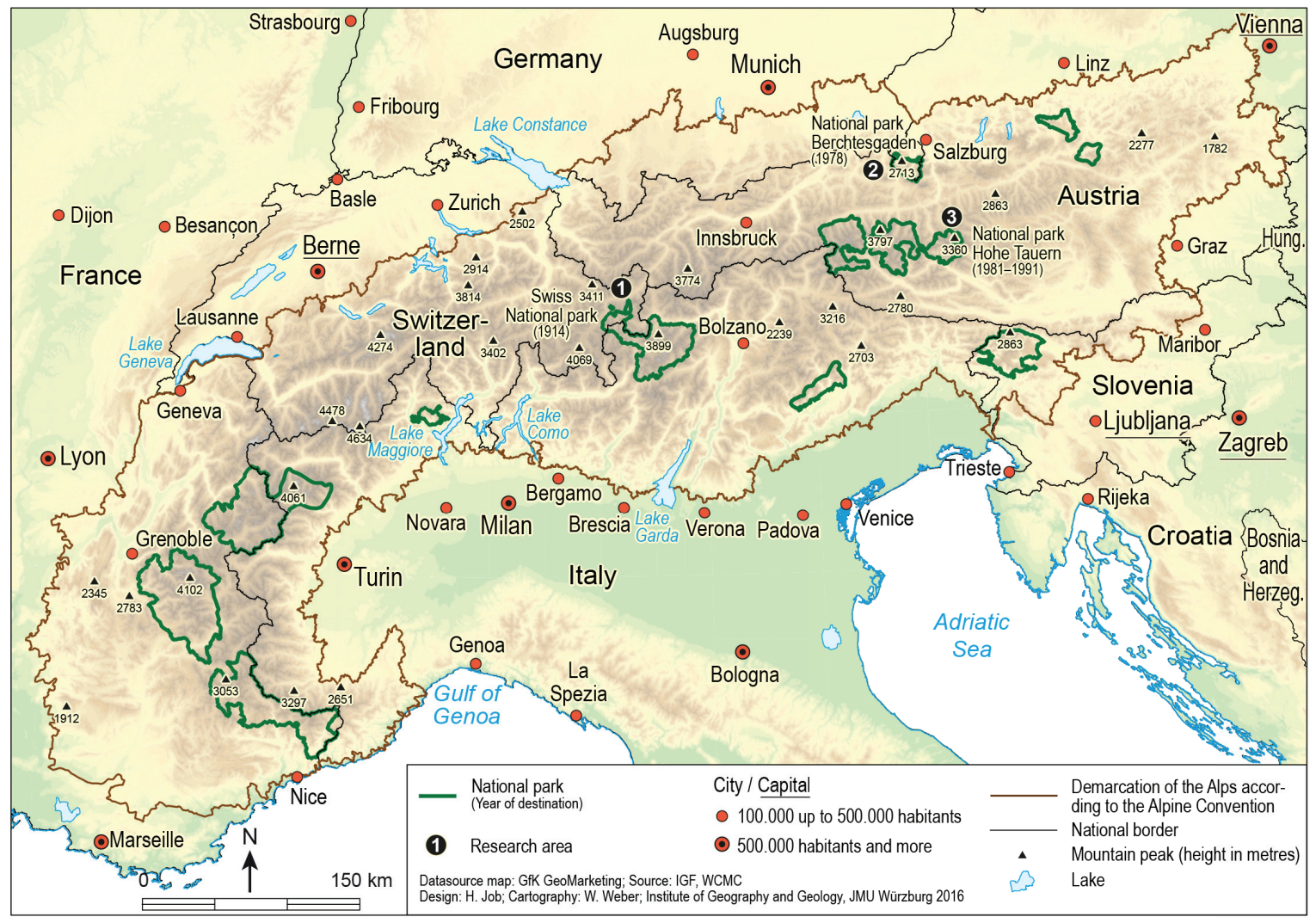

Figure 1 - Location of the three research areas - Swiss NP, Berchtesgaden NP and Hohe Tauern NP - within the Alpine Arc.

sources that refer to the development of the parks in a contemporary perspective, such as articles in newspapers and journals, reports of actors and, in selected cases, also laws, directives and administrative documents were also taken into account to obtain a differentiated picture. The transcribed interviews and nearly 1100 excerpts of the written sources were subjected to a qualitative text analysis conducted with the analysis-software ATLAS.ti 7. A list of approximately 650 codes in ten categories was extracted from these materials (Table 2). Co-occurrences between individual codes or clusters of codes were described in co-occurrence tables and made it possible to characterize conceptions of conservation during the further processing of the data. Actors, threats, goals and instruments emerged as fundamental categories to depict the different conservation conceptions. The system developed in this study can be used as framework for further investigations and can, if required, be continuously extended and restructured. To answer the research questions addressed in this paper, the co-occurrence tables were re-analysed according to the research context.

Austria, Germany and Switzerland are federal states with major legislative competencies at federal level. This leads to a high diversity in the nomenclature of quite similar legal instruments that can be neither used synonymously nor properly translated into English. This is why in this text the best fitting English terms are used and the original German terms are added in brackets.

\section{Results}

\section{Swiss NP (Switzerland)}

The park, established in 1914 in Unterengadin (canton of Graubünden) on the border with Italy, is the

Table 2 - Code-list owners and land users. Clustered codes of from Atlas-ti; figures indicate frequency of occurrence. (PichlerKoban \& Jungmeier 2015, adapted). SN=Swiss National Park, BG=Berchtesgaden National Park, HT=Hohe Tauern National Park

\begin{tabular}{|c|c|c|c|c|c|}
\hline Actors & Subgroup & & SN & BG & $\mathrm{HT}$ \\
\hline \multirow{15}{*}{$\begin{array}{l}\text { Owners } \\
\& \text { users }\end{array}$} & \multirow[t]{2}{*}{ Owners } & land owners & 0 & 3 & 14 \\
\hline & & public land owners & 1 & 0 & 4 \\
\hline & \multirow{3}{*}{$\begin{array}{l}\text { Producers, } \\
\text { land and } \\
\text { other users }\end{array}$} & agriculture & 0 & 14 & 20 \\
\hline & & forestry & 5 & 10 & 4 \\
\hline & & hunting/fishing & 11 & 10 & 12 \\
\hline & \multirow[t]{6}{*}{$\begin{array}{l}\text { Commer- } \\
\text { cial users }\end{array}$} & $\begin{array}{l}\text { trade and industry, min- } \\
\text { ing, construction }\end{array}$ & 0 & 2 & 10 \\
\hline & & power industry & 10 & 1 & 38 \\
\hline & & development \& transport & 0 & 3 & 6 \\
\hline & & investors & 0 & 0 & 0 \\
\hline & & tourism & 4 & 16 & 14 \\
\hline & & military & 0 & 6 & 0 \\
\hline & \multirow[t]{4}{*}{$\begin{array}{l}\text { Private } \\
\text { users }\end{array}$} & $\begin{array}{l}\text { mountaineers \& hobby } \\
\text { sportspeople }\end{array}$ & 1 & 8 & 7 \\
\hline & & $\begin{array}{l}\text { people from the vicin- } \\
\text { ity seeking recreation, } \\
\text { tourists }\end{array}$ & 7 & 9 & 4 \\
\hline & & local population & 11 & 13 & 18 \\
\hline & & specific social groups & 1 & 0 & 6 \\
\hline
\end{tabular}


Table 3 - Selected milestones in the development of the Swiss NP (PichlerKoban \& Jungmeier 2015, adapted).

\begin{tabular}{|l|l|}
\hline Year & Milestone/occurrence / development \\
\hline 1906 & $\begin{array}{l}\text { Schweizerische Naturschutzkommission (Swiss Conservation Commission) } \\
\text { founded with the intention to develop a network of protected sites }\end{array}$ \\
\hline 1909 & $\begin{array}{l}\text { Lease-agreement with the Community of Zernez to protect Val Cluozza for } \\
\text { the establishment of a national park }\end{array}$ \\
\hline 1914 & $\begin{array}{l}\text { Swiss National Park established by decision and announcement of the } \\
\text { Swiss Parliament }\end{array}$ \\
\hline 1944 & $\begin{array}{l}\text { Mass mortality of deer leads to debate on the strict non-intervention policy } \\
\text { of the park management }\end{array}$ \\
\hline 1957 & $\begin{array}{l}\text { Plebiscite decision allows for hydro-electric exploitation of the river Spöl } \\
\text { within the park's area and leads to increased publicity of the park }\end{array}$ \\
\hline 1958 & $\begin{array}{l}\text { All-time record in visitors' number challenges the park's management in } \\
\text { its resistance against tourism and touristic activities }\end{array}$ \\
\hline 1979 & Recognition of the park as UNESCO biosphere reserve \\
\hline 1996 & $\begin{array}{l}\text { Enforcement of a new national park law that provides a sound legal } \\
\text { foundation for the park }\end{array}$ \\
\hline 2000 & $\begin{array}{l}\text { In a referendum the community of Zernez unexpectedly rejects the exten- } \\
\text { sion of the National Park }\end{array}$ \\
\hline 2008 & New visitors' centre in Zernez opens \\
\hline
\end{tabular}

oldest NP in the Alps. The land is owned by five communities (Zernez, S-chanf, Scuol, Val Müstair, Lavin). Nowadays the park covers an area of some $170 \mathrm{~km}^{2}$ of high-alpine landscapes and ecosystems without human use for pasture, forestry or hunting for more than one century. Up to 150000 visitors per year make use of the park's facilities, and the road across the Ofenpass is a well-known scenic road cutting through the park (Backhaus 2013). The park is listed by IUCN as strict nature reserve (category 1a), "where human visitation, use and impacts are strictly controlled and limited", tourism is practically excluded (Dudley 2008). Some milestones of the park's development are outlined in Table 2.

The motivation for establishing the NP derived from scholarly intentions to explore the development of nature once all human uses were abandoned. The initiative was taken by the explorer Paul Sarasin, president of Schweizerische Naturschutzkommission (Swiss Commission of Nature Conservation) established in 1906. Inspired by the early American NPs, the idea was to select an area which would be declared absolute free for animals and plants and in which any human interference would be prohibited ("welches für Tiere und Pflanzen zum absoluten Freigebiet erklärt würde, im welchem also jeder Eingriff in den Bestand des pflanglichen und tierischen Lebens ausgeschlossen sein müßte" Schweizerische Naturschutzkommission 1909a). The search for an appropriate location for this experiment led to the valley of Cluozza, one of the economically least developed regions of the country. The communities were dependent on low-income farming and forestry and faced collapsing timber prices in the early $20^{\text {th }}$ century. Hence they welcomed the idea of a NP based on attractive lease agreements: In 1909 a first contract with the community of Zernez was signed and further communities should follow. The Swiss parliament proclaimed the NP in 1914 and gave way to scientific works that until today have shaped the park's identity and its designated use as open air laboratory

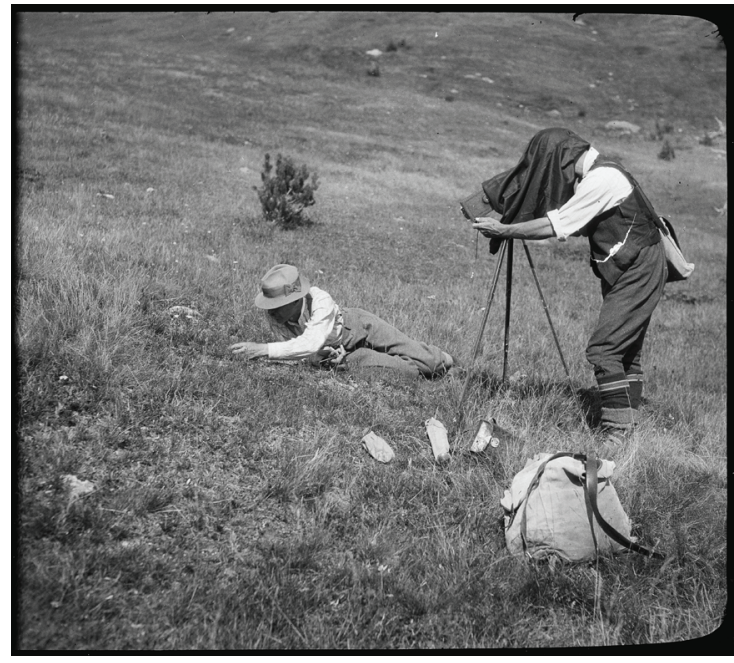

Figure 2 - Research as driving factor of the Swiss NP. (C) Swiss National Park archive

(Freiluftlaboratorium), as research area (Forschungsareal) and as reference area (Referenzfläche) (Haller 2013), Figure 2.

The fact that the valley of Cluozza had until then escaped the attention of tourism (Kupper 2012b), is considered to have encouraged scholarly visions and purposes. The founding fathers of the park were quite reluctant regarding touristic uses. Even the American model, which was generally well received because of its strict protection regimes, was rejected where it referred to "the benefit and enjoyment of the people" (Schweizerische Naturschutzkommission 1909b). Alpine tourism at that time was experiencing a significant upswing, but already began to be seen as a serious threat to the country's nature. This is why the Swiss NP aimed to protect the wonders of nature from "any further exploitation through greedy speculation" (Christ 1908 quoted in Kupper 2012b).

A few years after its foundation, the NP had already reached considerable popularity and attracted increasing numbers of visitors. While the great interest of the Swiss population in "our national project" was appreciated, the "bigher numbers of visitors brought also disadvantages" (Eidgenössische Nationalparkkommission 1927). Some examples of the adverse effects mentioned by the commission were rubbish left behind, people straying from the designated paths and impairments to animal and plant life. The commission even considered shutting down service in the Cluozza hut so as to make the stay in the park less enjoyable for visitors (Eidgenössische Nationalparkkommission 1927). Reports of the National Park Commission repeatedly documented complaints about the behaviour of visitors who left rubbish behind (listing wrapping paper, tins, glass) or considered the NP as appropriate sites for nudism (Eidgenössische Nationalparkkommission 1933). Park guards repeatedly had to reprimand visitors. For example, the following utterance by a guard is documented: "Switzerland is large and di- 
verse. Why of all places do you come to the national park?" (Schloeht 1989).

In the context of the European Year of Nature Conservation, the number of visitors reached a peak in 1971. The park management struggled with high levels of traffic and a lack of parking space, and complaints about "uninterested and superficial quick visitors" accumulated (Eidgenössische Nationalparkkommission 1981). Thus, a decline in visitors in 1984 was felt to be rather "positive, representing a relief" for the park management, whereas representatives of the tourism sector feared economic losses (Eidgenössische Nationalparkkommission 1984).

The image of tourism gradually changed from that of an adverse side effect to that of a cooperation partner. With the National Park Act of 1980, park communities obtained permanent representation in the National Park Commission, which forced an increased consideration of regional interests. More and more educational and leisure activities were being offered and step by step integrated into the range of tourist offerings. In 2007 reliable counting methods began, providing a good overview of visitor numbers and even allowing retrospective calculation thereof (Kupper 2012b). The visitor centre in Zernez, opened in 2008, hosts NP-related exhibitions as well as a tourist information service. Today the NP is part of the holiday region Engadin Scuol - Engadin Val Müstair which, responding to current trends, positions itself as all season nature and culture holiday region for all ages (Siegrist et al. 2015). On the occasion of its centenary, the NP was described as a "most important tourist attraction and brand of Zernez” (Lozza 2009).

\section{Berchtesgaden NP (Germany)}

The park in Southern Bavaria includes limestone rock masses with high relief energies, different altitudinal belts and iconic landscapes around the Watzmann massif and around Königssee. The total area of about $210 \mathrm{~km}^{2}$ is public land owned by the Free State of Bavaria. Since the Middle Ages land uses, in particular forestry, mining and hunting, have significantly changed the natural landscape that was designated as NP in 1978. Some milestones of the park's development are outlined in Table 4. IUCN lists Berchtesgaden NP in category II (National Park), obliging it to provide educational, recreational and visitor options.

In contrast to the fast, revolutionary implementation of the Swiss NP, the development of Berchtesgaden NP can be described as a slow, evolutionary process throughout the $20^{\text {th }}$ century. Individual disputes repeatedly resulted in the achievement of conservation objectives and, respectively, the expansion of protection regulations. The actual foundation of the NP 1978 took place at a time when the expansion of top level protected areas all over Europe was generally high up on the political agenda.

The area of Berchtesgaden had long been used for touristic purposes. For example, St. Bartholomew's

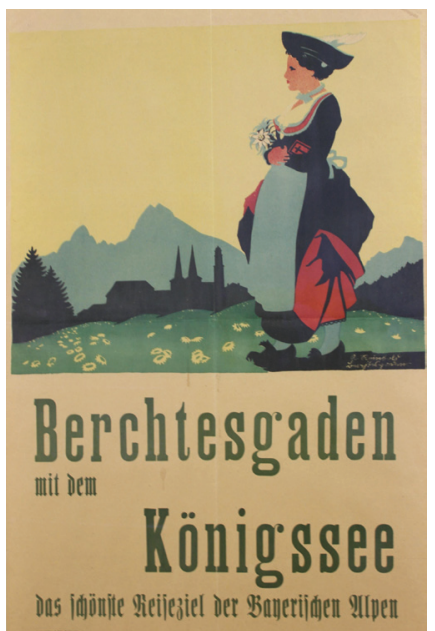

Figure 3 - Alpine tourism Berchtesgaden. Poster by Anton Reinbold (ca. 1910). (C) Berchtsgadener Land Tourismus Gmbh

church at Königssee has attracted pilgrims since the $17^{\text {th }}$ century. The Bavarian royals chose Berchtesgaden as their summer residence to indulge in their hunting passion. The connection of Berchtesgaden to the railway network in 1888 instantly turned it into a popular destination for Alpine tourists and day trippers (Figure 3).

In 1898 travel writer Heinrich Noë recommended preserving the Berchtesgadener Land as a "Yellowstone of the German Alps" (Zierl 1980). The forest botanist Carl Freiherr von Tubeuf and the Association for the Protection of Alpine Flora and Fauna (Verein zum Schutz der Alpenpflanzen und -Tiere) proposed to designate a protected area around the Königssee (Figure 4). In 1910 the Plant Reserve (Pflanzenschongebiet) Königssee was established (Zierl 1980).

Remarkable developments took place during the Third Reich. Referring to the great dangers of mass tourism for nature conservation, the then Chief of Forestry and Nature Conservation, Hermann Göring, declared the area around the Königssee a special nature reserve. There, as well as in the Danube wetlands and the Schorfheide, he could pursue his hunting interests undisturbed (Job 2010). Adolf Hitler and the entire leadership of the National Socialist Party had holiday homes in Berchtesgaden. Obersalzberg was turned into the Führer's off-limits area (Führersperrgebiet) in 1933.

After the Second World War, the scholar and President of the German League for Nature and Environment, Hans Krieg, proposed the establishment of a NP. From 1970 onwards various German and Austrian conservation authorities and associations worked to create a joint NP. Federal state authorities declared that this project was also intended to "ensure the development of the tourism sector" (Berchtesgadener Anzeiger 19/07/1969).

The local decision makers feared that they would lose their economic ties with other tourist regions and therefore invested in modernization. At that time, numerous plans for cable cars and lifts were devised (Job et al. 2014). Despite the protests of environmentalists, a ca- 
Table 4 - Selected milestones in the development of Berchtesgaden National Park (Pichler-Koban \& Jungmeier 2015, adapted).

\begin{tabular}{|c|c|}
\hline Year & Milestone / occurrence / development \\
\hline 1888 & $\begin{array}{l}\text { Connection to the railway system gives way to early touristic development } \\
\text { of the Berchtesgaden region }\end{array}$ \\
\hline 1910 & $\begin{array}{l}\text { Establishment of the Königssee plant reserve (Pflanzenschonbezirk Königs- } \\
\text { see) as a response to commercial exploitation of Alpine flora }\end{array}$ \\
\hline 1921 & $\begin{array}{l}\text { Establishment of the Königssee conservation area (Naturschutzgebiet) as } \\
\text { response to public discussion and conservationists' claims }\end{array}$ \\
\hline 1952 & $\begin{array}{l}\text { Bavarian parliament reduces the size of the conservation area to allow for } \\
\text { the construction of a cable car up the Jenner }\end{array}$ \\
\hline 1972 & $\begin{array}{l}\text { Decision to start a planning process for establishing a national park in } \\
\text { Bavaria }\end{array}$ \\
\hline 1978 & Establishment of Berchtesgaden National Park \\
\hline 1981 & $\begin{array}{l}\text { Launch of the MaB programme on ecosystems that initiates the research } \\
\text { tradition of the park }\end{array}$ \\
\hline 2003 & $\begin{array}{l}\text { Reform of the park's administrative structures which had been subject to } \\
\text { ongoing criticism }\end{array}$ \\
\hline 2013 & Opening of the Haus der Berge, setting new standards in visitor facilities \\
\hline
\end{tabular}

ble car was installed on the Jenner and the relevant area was no longer part of the nature reserve. Of all plans, it was the idea to construct a cable car on the Watzmann which led to the concretization of the long-held plans for a NP. For local politicians and the tourism industry the debate about the project turned into a question of economic survival: Anyone who did not believe in the economic necessity of the Watzmann cable car was accused of completely misjudging the gravity of the competitive situation (Müller 1969). Conservationists countered by pointing out that "without compelling necessity, a unique natural and recreational resort is endangered by a project the consequences of which are out of all proportion to its usefulness". Rumours about the reintroduction of wild animals in the area were considered outrageous by the mayor of Berchtesgaden, who believed that no visitor would dare hike in the mountains anymore if there were bears around. He argued that zoos hosted sufficient wild animals and that the NPs had turned into a "real disease" (Die Abendzeitung 13/01/1970).

In spite of all protests, the Bavarian authorities decided to establish a NP. After the foundation of the park in 1978, the Conservation Association (Bund Naturschutz) in Bavaria ceased its previously committed activities for the park, arguing that the park was overrun by tourists. The German Alpine Association (Deutscher Alpenverein) followed a similar strategy (Spemann 1977).

Tourism and conservation continued to view each other as proponents of opposed, mutually exclusive interests. In 1978 the debate around a 110kV overhead power line to be run through the valley of the Berchtesgadener Ache made the headlines. The joint rejection of the project by conservationists and tourism actors suddenly united the two camps and, among other factors, led to a gradual process of rapprochement.

Today tourism and NP cooperate in many respects. However, the NP brand has until recently only played a subordinate role in the highly developed, traditional destination of Berchtesgaden (Butzmann \& Job 2016).

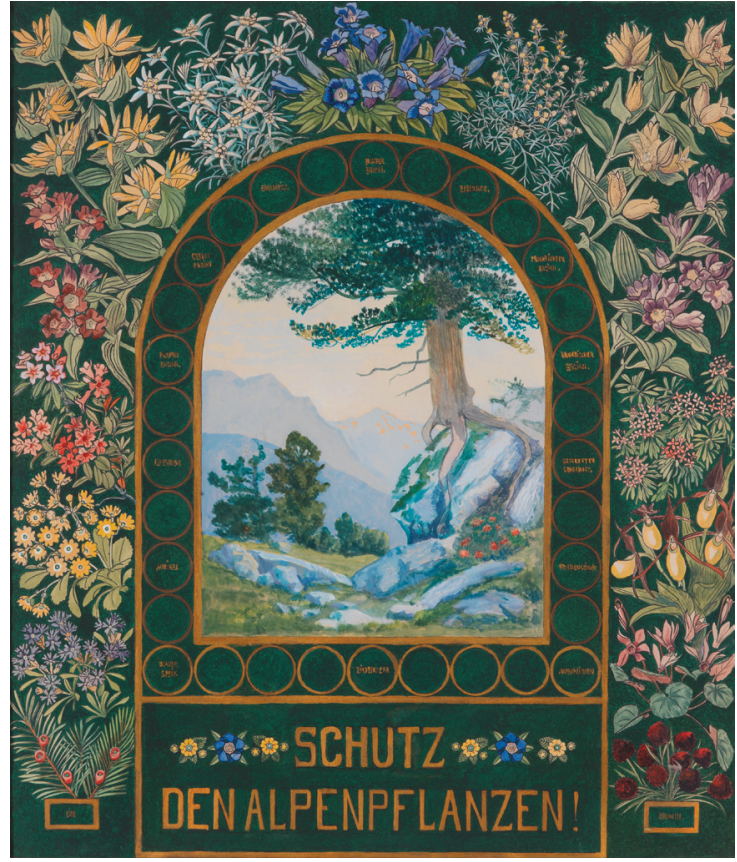

Figure 4 - Protect Alpine Flora. Poster by Gustav Jahn (1910). (C) Alpenvereinsmuseum Innsbruck

The opening of the Haus der Berge as an educational and information centre of the NP combines an attractive touristic option with the educational task of the NP. The Bavarian Minister of State for Environment and Consumer Protection has praised the NP as an economic model for success which, through NP tourism alone, has created more than 570 jobs (Nationalpark Berchtesgaden 2016). This figure refers to the current study of Job et al. (2016).

\section{Hohe Tavern NP (Austria)}

With a total area of about $1856 \mathrm{~km}^{2}$ the park is the largest protected area in the Alps. It covers the geological formation of the Tauernfenster, high-altitude ecosystems, including Austria's largest glacier, the Pasterze, and the country's highest mountain, the Großglockner (3798 m.a.s.l.). The park stretches across three federal states (Carinthia, Salzburg, Tyrol) and is predominantly on private land. The governance structures are very complex and involve three federal states, the Austrian Ministry of the Environment, hundreds of private land owners and even more co-owners of common land (co-operatives), plus a total of $30 \mathrm{com}$ munities in different boards, committees and funds. Evidently the principles of the Austrian social partnership have been transferred to the park's management (Kupper \& Wöbse 2013). Nowadays the park's facilities, including $4500 \mathrm{~km}$ of marked hiking trails, are used by up to 1.7 million visitors. Some milestones of the park's development are outlined in Table 5. ICUN lists Hohe Tauern NP in category II (National Park), some of the lateral zones are recognized as protected landscape category V. In both categories tourism plays an important role. 


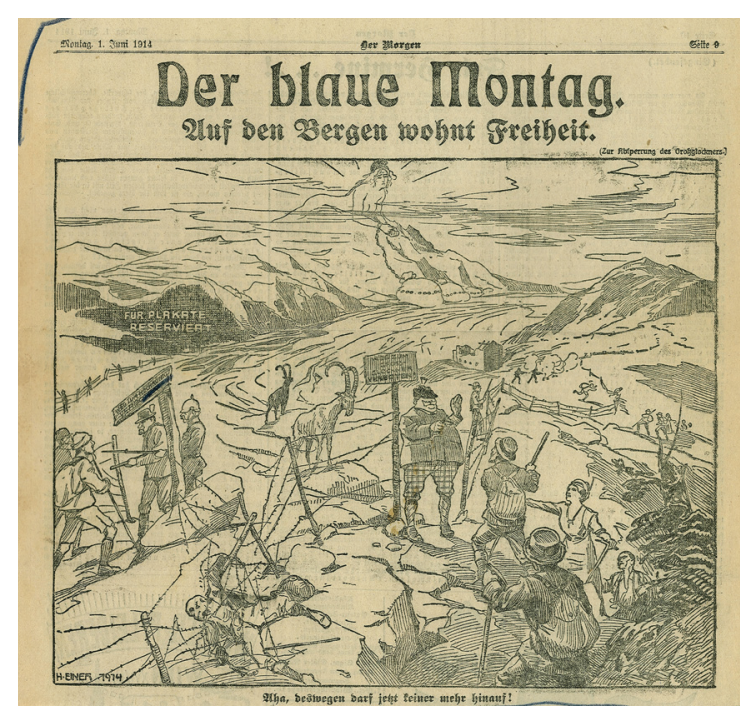

Figure 5 - Early debate about a public right of way. Cartoon by H. Einer (1914). (C) OeAV-Archiv Innsbruck.

The story of Hohe Tauern NP starts in the early years of the $20^{\text {th }}$ century and, after countless intermediate steps, reached a temporary end in 2006 with the international recognition by the IUCN of the Salzburg part of the NP. While the early years were marked by scepticism of environmentalists towards touristic over-usage of the park, the debate around hydropower utilization soon became a priority issue.

Even when natural monuments in Carinthia were first declared in 1904, the possibility of using them as "points of attraction for foreigners" was taken into account (Anonymus 1904). With the completion of the Tauern railway in 1909, the Hohe Tauern, which had already been popular among alpinists before, got connected to the urban centres and experienced an upswing in tourism. In this context, first plans for further touristic infrastructure were devised, for example, plans for an exclusive hotel with summer skiing possibilities on the Pasterze glacier in the Gamsgrube opposite the Großglockner (Figure 5). These plans served as an incentive for Albert Wirth, a businessman from Villach, to buy an area of $42 \mathrm{~km}^{2}$ around the Großglockner (Draxl 1996). He entrusted the German-Austrian Alpine Association (Deutsch-Österreichischer Alpenverein) with the administration of this area, with a mandate to maintain it as a "nature reserve for the future" and to protect it from the "speculative Alpine tourism industry" (Hasenöhrl 2013). Two years before that, the German Naturschutzpark Association (Verein Naturschutzpark) had bought land in the Stubach Valley in order to establish a nature reserve.

Subsequently several disputes arose around touristic infrastructure projects, e.g. in the Großglockner area. The Alpine associations tried to prevent these projects using conservation arguments. What is interesting is that while the Alpine associations rejected hotel, cable car and climbing assistance projects, they accepted
Table 5 - Selected milestones in the development of Hohe Tauern National Park (Pichler-Koban \& Jungmeier 2015, adapted).

\begin{tabular}{|c|c|}
\hline Year & Milestone/occurrence/development \\
\hline 1912 & $\begin{array}{l}\text { Acquisition of land in Stubachtal and Felbertal by the Nature Park Associa- } \\
\text { tion (German Verein Naturschutzpark) in order to establish a nature park }\end{array}$ \\
\hline 1918 & $\begin{array}{l}\text { Entrepreneur Albert Wirth's acquisition of Großglockner and Pasterze } \\
\text { glacier and their designation as nature park of the future }\end{array}$ \\
\hline 1935 & $\begin{array}{l}\text { Opening of Großglocker High Alpine Road after five years of construction } \\
\text { and paradigmatic disputes between conservation and touristic develop- } \\
\text { ment actors }\end{array}$ \\
\hline 1953 & $\begin{array}{l}\text { Plans for hydro-electric exploitation of the Krimml waterfalls abandoned } \\
\text { after a campaign had collected more than } 120000 \text { signatures against the } \\
\text { project }\end{array}$ \\
\hline 1971 & $\begin{array}{l}\text { Treaty of Heiligenblut signed between three federal states to establish } \\
\text { Hohe Tavern National Park on the occasion the European Year of Con- } \\
\text { servation }\end{array}$ \\
\hline 1983 & Establishment of the Hohe Tavern National Park in Carinthia \\
\hline 1983 & Estabishment of the Hohe Tauern National Park in Salzburg \\
\hline 1993 & Establishment of the Hohe Tauern National Park in Tyrol \\
\hline 2006 & Recognition of the park by the World Conservation Union (IUCN) \\
\hline 2007 & $\begin{array}{l}\text { Opening of Mittersill National Park Worlds (Nationalparkwelten) visitor } \\
\text { centre that would break all records in term of visitors' numbers }\end{array}$ \\
\hline
\end{tabular}

road projects such as the Großglockner High Alpine Road practically without resistance. Only the plans for an access road to the Franz-Josephs-Höhe sparked a heated and polemic debate (Hasenöhrl 2013). When the north ramp of the Großglockner High Alpine Road was opened in 1935 after a five-year construction period, it was celebrated as an "exemplary presentation and interpretation of a high Alpine landscape" and as a new symbiosis of art and nature (Leitner 2003).

During the Third Reich, the National Socialist regime planned to create a German Hohe Tauern National Park as a recreation area. The first step to achieve this goal was to put large parts of the Hohe Tauern in Salzburg under landscape protection and to declare parts of the Hohe Tauern in Carinthia (Maltatal, Gößgraben) a nature conservation area (Stöger 2013).

After the Second World War, conflicts between nature protection and the booming energy industry developed. In the context of this confrontation, conservation and tourism pulled together to achieve their common objectives. Already during the Third Reich, there had been plans for power plants in the Hohe Tauern that would ensure energy supply for the whole of Germany. However, scarcity of resources during the war prevented this project. In post-war Austria demand for energy was enormous and the energy industry needed little argument for the expansion of their power plants (Schmid \& Veichtlbauer 2006). The usage of the Krimml waterfalls for power generation could be prevented through a nationwide campaign. Conservationists argued that nobody could understand the destruction of these "internationally famous sights and their impact on tourism" (Wendelberger 1950). Political decision makers, too, considered the Hohe Tauern as an "invaluable asset of tourism" (Machura 1951) (Figure 6).

An important milestone in the history of the NP was the 1971 Contract of Heiligenblut in which the 


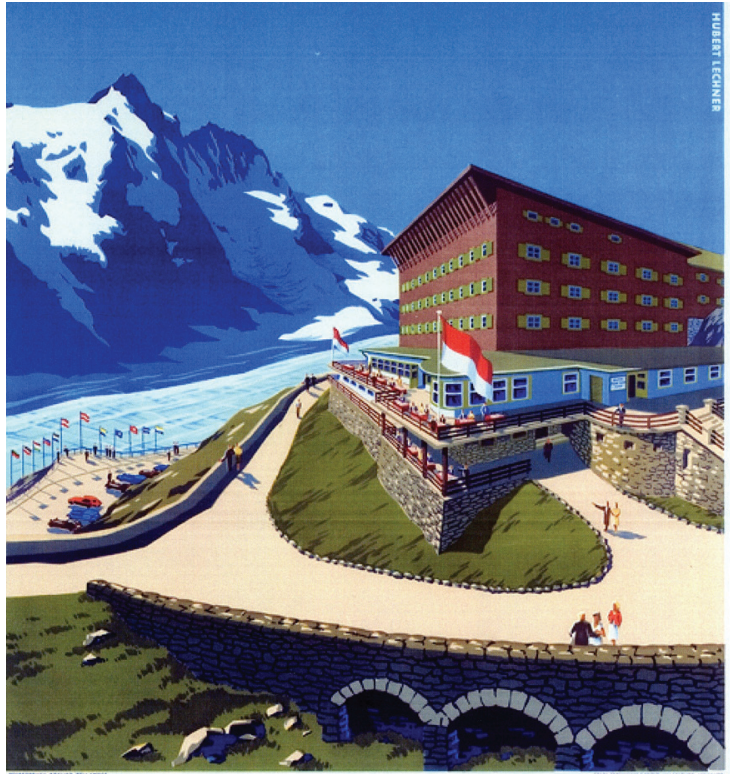

GRRSSGLDCKNER $3799_{m}$ [ARINTHIA ALPINEHOTEL KAISER FRANZ-JOSEPH-HAUS GRUSSGLOCKNER-HIGH-ALPINE-ROAD

\section{AUSTRIA}

Figure 6 - Destination Hohe Tauern. Großglockner, Pasterze, Kaiser Franz-Josephs-Haus. Poster (ca. 1950). (C) Kärntner Landesarchiv, Plakatsammlung A 276

federal states of Carinthia, Salzburg and Tyrol laid the foundation for the creation of a NP. Referring to the 1970 European Conservation Year, they agreed to "conserve the Hohe Tauern [...] in their originality and beauty [...] for the good of society, science and the economy for all time" (Floimair et al. 1985). The approaches of sustainable tourism, emerging in the 1980 s, were considered useful concepts in this regard.

In 2012 the tourism officer of Hohe Tauern NP demanded that the protected areas and the tourist regions work together for the "development of sustainable, service-providing and value-generating nature tourism" (Mussnig 2012). The park today offers a wide range of options for visitors. A good example of this kind of NP tourism is the visitor centre of the National Park Worlds in Mittersill, opened in 2007.

\section{Discussion}

Identifying conservation conceptions

The analysis of the data revealed six conceptions figuring prominently in the discourse between actors from conservation and tourism.

\section{Conception 1 - Fundamental antagonism}

The predominant narrative of this conception draws on the integrity and beauty of nature that gets disturbed and destroyed by any kind of human

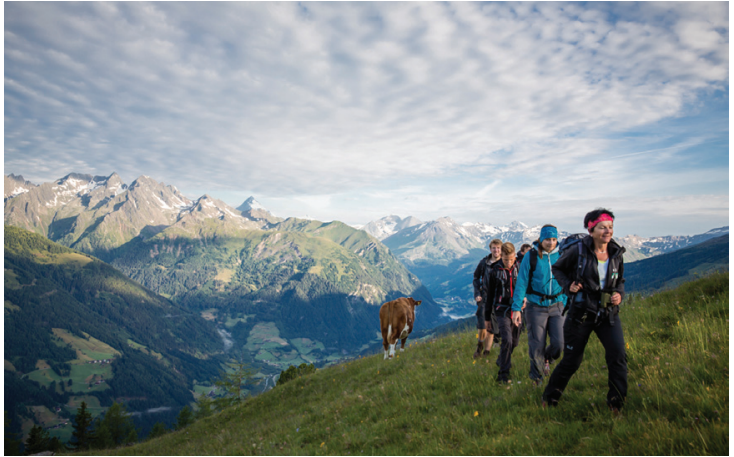

Figure 7 - Magic Moments. Cooperation between parks and tourism, example of Hohe Tauern National Park Carinthia. (C) Martin Steinthaler, Hobe Tauern NP

intervention. Unspoilt nature must be protected against overwhelming human exploitation. Only few (educated) visitors know how to behave; all others are a permanent and immanent threat to fauna and flora and must therefore be excluded. This conception is favoured and promoted by urban, mainly scientific elites, who have become particularly influential at the turn of the century. They advocate for the exclusion of all human activities other than nature observation and science. Evidently the exclusiveness of this position calls for exclusive instruments and can most effectively be implemented by economic instruments such as purchase or lease of land. This is where the patronage of the early $20^{\text {th }}$ century comes in. The case studies in this article provide evidence that ownership has been a fundamental pillar to push forward conservation interests.

\section{Conception 2 - Selective antagonism}

Paradigmatically, this position claims that Alpine nature and landscapes are hideaways from an everyday life that is more and more dominated by emerging technologies, traffic and urban lifestyles. Mountains allow people to gain self-awareness and are sites for emotional, social and spiritual experiences in close, archaic contact with nature. These Alpine landscapes are in danger of being spoilt by noisy mass tourism, technical infrastructures, modern architecture and new technologies in agriculture or forestry. This conception is formed and advocated by Alpine associations and mountaineering clubs, the early pioneers of Alpine tourism. Primarily these were rooted in welleducated, well-off circles of public and academic life, but have continuously widened their member base throughout the $20^{\text {th }}$ century. As a result, these actors became the most influential drivers of a public debate that opposed infrastructures such as ski resorts, cable cars, hydroelectric power plants and grids in Alpine regions. It is obvious that the actors have great confidence in legal instruments, regulatory planning and public administration. Dirigistic instruments, such as Tyrolian refugia (Ruhegebiete, Pangerl 1993) or the Alpenplan of Berchtesgaden (Job et al. 2014) may be seen 
as prototype instruments for this conception. So the whole variety of legal instruments is advocated and promoted, including directives and laws, spatial planning, limitations and - later - international conventions and standards. Many instruments are used to influence public opinion and to gain access to political decision makers.

\section{Conception 3 - Opportunistic co-operation}

There is no particular narrative in this regard, since the position refers to the concrete discourses and arguments used. However, a supposedly strong interest is assumed to support conservationists' positions, e.g. with the argument that a project will lead to a loss of touristic opportunities. For example, in Hohe Tauern opponents of the exploitation of Gamsgrube argued that the loss of natural beauty would also mean a loss of the inestimable fundamentals for the tourism industry (Natur und Land 1951). This conception is used by different groups, but mainly by civil society actors. It is hard to distinguish between what is honest conviction and what is already a compromise, making any interpretation of this position problematic. Mainly these opportunistic co-operations are limited in time. They are focused on a particular topic, but remain fragile and not binding for both the sides. The strategy clearly intends to influence public opinion and decision makers and as such is an instrument of agitation.

\section{Conception 4 - Opportunistic appropriation}

There is no general position in this respect, since the actors use conservationist arguments against tourism to support other private or institutional intentions. The case of the special nature reserves (Naturschutrgebiete spezieller Ordnung) that were designed and designated to enable exclusive hunting activities are the most prominent examples among the few cases that could be identified in the historic materials. As matter of fact many protected areas go back to aristocratic hunting grounds and rights, yet this appropriation is unique.

\section{Conception 5 - Co-operative development}

This conception is based on the idea that most conflicts between conservation and tourism can be solved by technical solutions for visitor management. A partnership between the antagonistic camps enables good solutions satisfying the visitors and at the same time fulfilling conservationist requirements. Historically this conception is the first approach that involves park administrations, since no other institution has the necessary institutional and technical competencies. Park authorities act in cooperation and collaboration with tourism agencies, touristic service providers and tourism associations; the solutions quite often are of an informal nature and can be handled quite flexibly. According to Schwarz (2003), an institution comes into being in order to handle societal conflicts. In this light a park authority is the institution that is capable of successfully managing an obvious dilemma. Not surpris- ingly, this conception is prominently represented in recent approaches towards the management of parks and also fundamental for the IUCN's understanding of NPs (Dudley 2008).

\section{Conception 6 - Integrative development}

Recently it appears that administrations of $\mathrm{Al}$ pine parks are increasingly becoming touristic actors themselves, who still work in close co-operation with (other) touristic partners, but create their own attractive touristic options. One indication for this may be visitor centres with capital-intensive landmark architecture, outstanding edutainment facilities and competitive touristic services. Other indicators of NPs' efforts in this regard are touristic packages on offer and many activities related to destination development and branding (Job et al. 2016). This synthesis of parks and tourism is definitely generating "new forms of performance delivery" (Lange \& Jungmeier 2014) of the parks that go beyond what early conservationists could have imagined (Figure 7). This also indicates that the distinction between different IUCN categories has become vague or might become so. This applies to many different categories of protected areas, even including heritage sites. Some of these aspects are outlined in the concept of Parks 3.0., which has recently been developed in a European process of discussion (Lange \& Jungmeier 2014).

\section{Occurrence of conceptions over time}

When it comes to tracking these conceptions over time, we can observe a fluidity of conceptual patterns. The emergence of a new conception can be connected to particular societal developments and placed in a historical context. However, different conceptions co-exist at the same time; some of them seem to stay latent for a certain time and get re-discovered or re-animated as conceptual atavisms at any time (Figure 7).

\section{Swiss NP}

Clearly the predominant conception has been a fundamental antagonism (conception 1), shifting in the 1970s and 80s partly towards a more selective antagonism (conception 2). Nowadays there is a clear indication that integrative development (conception 6) is gaining in importance. No other conceptions could be identified in the materials. It is consequent that the park is designated as IUCN category 1a (strict nature reserve).

\section{Berchtesgaden NP}

Berchtesgadener Land had been a touristic region for a long time, hence tourism was never questioned per se. The pre-dominant conception of conservation had always been selective antagonism (conception 2), so the main discourse was about the question of what kind of tourism and what type of touristic offerings would be appropriate. The materials also allowed us to identify other conceptions $(3,4,5)$, but with a more temporary 

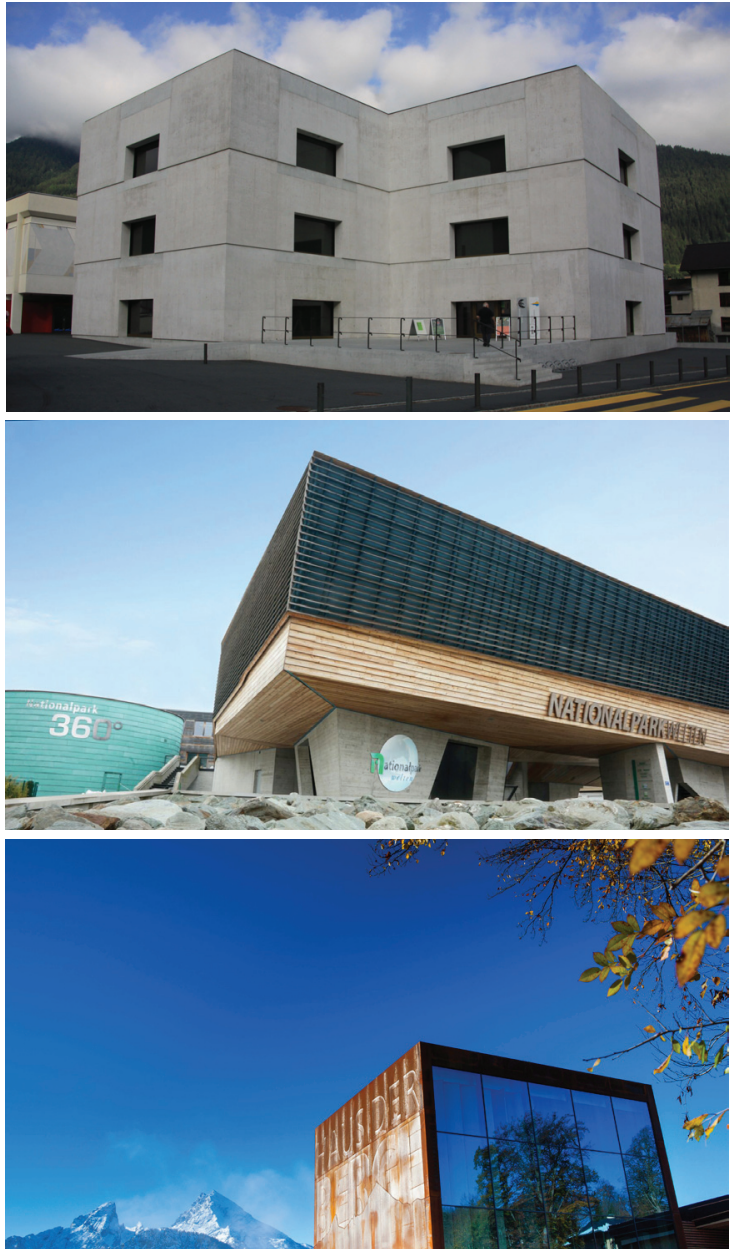

Figure 7 - Visitors centres as landmarks. Swiss NP (Zernez), Berchtesgaden NP (Berchtsgaden), Hohe Tauern NP (Mittersill). (C) E.C.O. Jungmeier; Hohe Tauern NP Salzburg; Berchtesgaden NP

character. Certainly the development of the park has changed the perception of tourism from opponent to ally. However, the discussions have not yet come to an end (Butzmann \& Job 2016). In the last decade integrative development (conception 6) has emerged.

\section{Hohe Tavern NP}

Similarly to Berchtesgaden NP, selective antagonism (conception 2) has been the prevailing conception of conservation for almost a century. To a certain extent the debate about tourism was a debate about technologies: public means of transport, such as cable cars and lifts, were understood as indicators of mass-tourism, whereas roads were not much under debate. In the large-scale conflicts related to hydropower plants, opportunistic co-operation (conception 4) played an important role. Nowadays the integrative development (conception 6) has become predominant; the park is an important touristic actor and has become shareholder of the regional tourism association.

The historic analysis indicates that Alpine parks, with different historical backgrounds and initial perspectives, seem to have increasingly aligned their ap- proaches over time, which suggests that they may become institutions with similar cultures, i. e. regional fractals that have become cornerstones of ecological globalization (Lange \& Jungmeier 2014).

From a purely practical point of view these results once again indicate that conservation in general and protected areas in particular are not concepts that are solely or mainly based on natural sciences. The perception of nature and the definition of desirable features and functions of nature evolve in complex societal developments and permanent debates. These need to be understood by planners, managers and promotors of protected areas, since the paradigms are constantly changing. This makes debates and reflective discourses with society in general and relevant stakeholders in particular vital exercises.

\section{Acknowledgements}

We would like to thank the Bristol Foundation for their generous support, which enabled a large-scale study on the history of Alpine protected areas. In particular we would like to thank Dr. Mario Broggi, who contributed to this study as expert, discussion partner and mentor. We are also grateful towards all interview partners, contemporary witnesses, archivists and scientific consultants. Many of them have expressed their interest in the project even after completion of this study, forwarded additional information and encouraged us to pursue research in this area. Finally, we want to thank all persons and institutions who made their historical and documentary picture material available.

\section{References}

Anonymus 1904. Erhaltung der Naturdenkmale in Kärnten. Carinthia II. 94: 51-56. Klagenfurt. [In German]

Backhaus, N. 2013. The Zen of driving a motorcycle through a national park: Reconciling grouporiented with practice-oriented research approaches. In: Conference Vol. $5^{\text {th }}$ Symposium for Research in Protected Areas, 10-12 June 2013: 39-42. Mittersill.

Becken, S. \& H. Job 2014. Protected areas in an era of global-local change. Journal of Sustainable Tourism 22(4): 507-527.

Berchtesgadener Anzeiger 19.07.1969. Alpenraumerschließung durch Bergbahnen. [In German]

Brüggemeier, F.-J. \& J.I. Engels 2005. Natur- und Umweltschutz nach 1945. Konzepte, Konflikte, Kompetenzen. Geschichte des Natur- und Umweltschutzes 4. Frankfurt. [In German]

Butzmann, E. \& H. Job 2016. Developing a typology of sustainable protected area tourism products. Journal of Sustainable Tourism. Available at: http://dx.doi.org/1 0.1080/09669582.2016.1206110

Die Abendzeitung 13.01.1970. Bären nichts für Sommerfrischler. [In German] 
Dowie, M. 2009. Conservation refugees. The hundred-year conflict between global conservation and native people. Massachusetts.

Draxl, A. 1996. Der Nationalpark Hohe Tauern. Eine österreichische Geschichte. Band 1. Von den Anfängen bis 1979. Alpine Raumordnung 12. Innsbruck. [In German]

Dudley, N. 2008. Clarifying the IUCN definition of a protected area. In: Dudley, N. \& S. Stolton (eds.), Defining Protected Areas: an international conference in Almeria, Spain, May 2007: 22-25. Gland.

Eidgenössische Nationalparkkommission 1927. Jahresbericht der Eidgenössischen Nationalparkekommission. [In German]

Eidgenössische Nationalparkkommission 1933. Jahresbericht der Eidgenössischen Nationalpark.kommission. [In German]

Eidgenössische Nationalparkkommission 1981. Schweizerischer Nationalpark. Jahresbericht der Eidgenössischen Nationalparkkommission. [In German]

Eidgenössische Nationalparkkommission 1984. Schweizerischer Nationalpark. Jahresbericht der Eidgenössischen Nationalparkekommission. [In German]

EUROPARC Federation 2009. Living Parks - 100 Years of National Parks in Europe. München.

Farkas, R. 2013. Umrisse einer Geschichte der Naturschutzbewegung bis 1970. Der Naturschutzbund und die Geschichte der Naturschutzbewegung. In: Jubiläumsheft Natur \& Land 99(1/2): 12-20. Salzburg. [In German]

Flint, C.G., I. Kunze, A. Muhar, Y. Yoshida \& M. Penker 2013. Exploring empirical typologies of human-nature relationships and linkages to the ecosystem services concept. Landscape and Urban Planning 120: 208-217.

Floimair, R., W. Retter \&. E. Graze 1985. Nationalpark Hohe Tauern. Der Kärntner Anteil. Salzburg. [In German]

Franke, N.M. \& U. Pfenning (eds.) 2014. Kontinuitäten im Naturschutz. Baden-Baden. [In German]

Gepp, J. 2013. Der Naturschutzbund im Umwelt-Zeitalter. Im Zeitraffer von 1970 bis heute. Jubiläumsheft Natur \& Land 99(1/2): 22-26. Salzburg. [In German]

Gissibl, B., S. Höhler \& P. Kupper (eds.) 2012. Civilizing Nature. National Parks in Global Historical perspective. New York.

Giddens, A. \& P.W. Sutton 2013. Sociology. Cambridge.

Haller, H. 2013. Vorwort. In: Haller, H., A. Eisenhut \& R. Haller (eds.), Atlas des Schweizerischen Nationalparks. Die ersten 100 Jahre. Nationalparkforschung Schweiz 99(1): 10-11. Bern. [In German]

Hammer, T., I. Mose, T. Scheurer, D. Siegrist \& N. Weixlbaumer 2012. Societal research perspectives on protected areas in Europe. eco.mont 4(1): 5-12. Innsbruck.

Hasenöhrl 2013. Naturschutz in der Zwischenkriegszeit (1918-1913). In Kupper, P. \& A.-K. Wöbse (eds.), Geschichte. Wissenschaftliche Schriften Nationalpark Hohe Tauern: 39-63. Mittersill. [In German]
Hammer, T. \& D. Siegrist 2008. Protected Areas in the Alps. The Success Factors of Nature-Based Tourism and the Challenge for Regional Policy. GAIA S1 (2008): 152-160. Konstanz, St. Gallen, Zürich.

IUCN 2013. What is a protected area? Available at: https://www.iucn.org/about/work/programmes / gpap_home/pas_gpap/ (accessed 09/05/2016)

Job, H. 2010. Welche Nationalparke braucht Deutschland? Raumforschung und Raumordnung 68(2): 75-89. [In German]

Job, H., S. Becken \& P. Sacher 2013. Wie viel Natur darf sein? Schutzgebietskonzepte im Wandel der Zeit. Standort 37: 204-210. Berlin, Heidelberg. [In German] Job, H., M. Mayer \& F. Kraus 2014. Die beste Idee, die Bayern je hatte: der Alpenplan. Raumplanung mit Weitblick. GAIA 23(4): 335-345. München. [In German]

Job, H., C. Merlin, D. Metzler, J. Schamel \& M. Woltering 2016. Regionalwirtschaftliche Effekte durch Naturtourismus in deutschen Nationalparken als Beitrag zum Integrativen Monitoring-Programm für Großschutzgebiete. BfN-Skripten 431. Bonn. [In German]

Knaus, F. 2012. Bedeutung, Charakteristiken und wirtschaftliche Auswirkungen des Sommertourismus in der UNESCO Biosphäre Entlebuch. - Resultate einer umfassenden Gästebefragung. Entlebuch. [In German]

Kupper, P. 2012a. Translating Yellowstone. Early European National Parks, Weltnaturschutz and the Swiss Model. In: Gissibl, B., S. Höhler \& P. Kupper (eds.), Civilizing Nature. National Parks in Global Historical Perspective 1: 123-139. New York.

Kupper, P. 2012b. Wildnis schaffen - eine transnationale Geschichte des Schweizerischen Nationalparks. Nationalpark-Forschung Schweiz 97. Bern, Stuttgart, Wien. [In German]

Kupper, P., U. Hasenöhrl, G. Stöger, O. Veichtlbauer, A.-K. Wöbse \& R. Würflinger 2014. History of Hohe Tauern National Park: a case in point of use and protection. eco.mont 6(1): 63-66. Innsbruck.

Kupper, P. \& B.C. Schär 2015. Die Naturforschenden: Auf der Suche nach Wissen über die Schweiz und die Welt 1800-2015. Baden. [In German]

Kupper, P. \& A.-K. Wöbse 2013. Schluss. In: Kupper, P. \& A.-K. Wöbse (eds.), Geschichte. Wissenschaftliche Schriften Nationalpark Hohe Tauern: 173-178. Mittersill. [In German]

Lange, S. \& M. Jungmeier 2014. PARKS 3.0 - Protected Areas for the next Society. Proceedings in the Management of Protected Areas 6. Klagenfurt.

Langer, J. 1991. Nationalparks im regionalen Bewußtsein - Akzeptanzstudie „Hohe Tauern“ und „Nockberge“ in Kärnten. Kärntner Nationalparkschriften 5. Klagenfurt. [In German]

Leitner, R. 2003. Kurze Geschichte des bürgerlichen Naturschutzes in Österreich von den Anfängen bis 1945. Unpublished manuscript. Graz. [In German]

Lozza, H. 2009. 1. Dezember 2009: 100 Jahre Nationalpark. Available at: http://www.nationalpark. $\mathrm{ch} / \mathrm{de} /$ about/mediencorner/medienmitteilungen/ 
medienmitteilungen-20101/2-dezember-2009-100jahre-nationalpark/ (accessed 30/04/2016) [In German]

Machura, L. 1951. Zum Geleit! Natur und Land. Sonderheft Schutz der Gamsgrube! 37(7/8): 113-115. Salzburg. [In German]

Müller, R. 1969. Watzmannbahn und Schizirkus Schneibstein. Stellungnahme des Landratamts. Berchtesgadener Anzeiger 27.3.1969. [In German]

Mussnig, G. 2012. Naturerlebnis Kärnten - eine Symbiose aus Schutzgebieten und Tourismus. Unpublished presentation.

Nationalpark Berchtesgaden 2016. Ein wirtschaftliches Erfolgsmodell. Pressemitteilung vom 11.3.2016. Available at: http://www. nationalpark-berchtesgaden.bayern.de/medien/ pressemitteilungen $/ 2016 /$ detailansicht.htm?ID $=$ BT B5ZwrxX0hQ\%2BB6ogZIIWA\%3D\%3D (accessed 28/04/16) [In German]

Natur und Land 1951. Sonderheft Schutz der Gamsgrube! 37(7/8). Salzburg. [In German]

Österreichischer Alpenverein (ed.) 1989. AlbertWirth-Symposium Gamsgrube (Heiligenblut). Tagungsbericht. Alpine Raumordnung. Fachbeiträge des Österreichischen Alpenvereins 2. Innsbruck. [In German]

Pangerl, K. 1993. Naturinventar Ruhegebiet Zillertaler Hauptkamm. Alpine Raumordnung 6. Innsbruck. [n German]

Pichler-Koban, C. 2013. Zeitreise durch den Naturschutz. In: Golob, B., M. Jungmeier. \& E. Kreimer (eds.), Natur \& Mensch in der Schütt. Die Bergsturzlandschaft im Naturpark zwischen Dobratsch und Gail: 28-35. Klagenfurt. [In German]

Pichler-Koban, C. \& M. Jungmeier 2015. Naturschutz, Werte, Wandel. Die Geschichte ausgewählter Schutzgebiete in Deutschland, Österreich und der Schweiz. Bristol-Schriftenreihe 46. Bern. [In German]

Pichler-Koban, C. \& M. Jungmeier 2016. Zur Institutionalisierung von Naturschutz im 20. Jahrhundert: ausgewählte Aspekte der Naturschutzgeschichte Kärntens - das Beispiel Naturpark Dobratsch. In: Carinthia I, Zeitschrift des Geschichtsvereins für Kärnten: i.p. Klagenfurt. [In German]

Radkau, J. \& F. Uekötter 2003. Naturschutz und Nationalsozialismus. Frankfurt. [In German]

Schloeth, R. 1989. Die Einmaligkeit eines Ameisenhaufens. Tagebuch aus dem Schweizerischen Nationalpark. Bern, Bonn, Wien. [In German]

Schmid, M. \& O. Veichtlbauer 2006. Vom Naturschutz, zur Ökologiebewegung. Umweltgeschichte Österreichs in der Zweiten Republik. Innsbruck. [In German]

Schmoll, F. 2004. Erinnerung an die Natur. Die Geschichte des Naturschutzes im deutschen Kaiserreich. Geschichte des Natur- und Umweltschutzes 2. Frankfurt. [In German]

Schwarz, G. 2003: Konfliktmanagement. Konflikte erkennen, analysieren, lösen. Wiesbaden. [In German]
Schweizerische Naturschutzkommission 1909a: Eingabe an den Zernezer Gemeinderat. Jahresbericht 1908/1909: 52-57. Lausanne. [In German]

Schweizerische Naturschutzkommission 1909b: Gutachten über die Gesetze der amerikanischen Reservationen. 3. Jahresbericht 1908/1909: 43-47. Lausanne. [In German]

Siegrist, D. \& M. Stremlow (eds.) 2009. Landschaft Erlebnis Reisen. Naturnaher Tourismus in Pärken und UNESCO-Gebieten. Zürich. [In German]

Siegrist, D., S. Gessner \& L. Bonnelame 2015. Naturnaher Tourismus. Qualitätsstandards für sanftes Reisen in den Alpen. Bristol-Schriftenreibe 44. Bern. [In German]

Spemann, E. 1977. Alpenverein droht mit Boykott. Münchner Merkur, 24. 1. 1977. [In German]

Stöger, G. 2013. Der Weg zum Nationalpark. Die Rolle des Naturschutzbundes vom Entstehen der Idee eines „Alpenparks“ bis zur Etablierung des Nationalparks Hohe Tauern. Jubiläumsheft Natur \& Land 99(1/2): 29-33. Salzburg. [In German]

Uekötter, F. 2004. Naturschutz im Aufbruch. Eine Geschichte des Naturschutzes in Nordrhein-Westfalen 1945-1980. Geschichte des Natur- und Umweltschutzes 3. Frankfurt. [In German]

Wendelberger, G. 1950. Rettet das Gesäuse! Rettet die Krimmler Fälle! Natur und Land 36(9/10): 145154. Salzburg. [In German]

Wöbse, A.-K. 2012. Weltnaturschutz. Umweltdiplomatie in Völkerbund und Vereinten Nationen 1920 1950. Geschichte des Natur- und Umweltschutzes 7. Frankfurt. [In German]

Zierl, H. 1980. Nationalpark Berchtesgaden. Geschichte eines Schutrgebiets. Berchtesgaden. [In German]

\section{Authors}

\section{Christina Pichler-Koban}

Department of Conservation history at E.C.O. Institute of Ecology. Her main focus of research is the analysis of the interaction between society and conservation, as well as the history and development of conservation paradigms from a historic and current perspective. E.C.O., Lakesidepark, B07, 9020 Klagenfurt, Austria. E-mail: pichler-koban@e-c-o.at

\section{Michael Jungmeier}

Head of E.C.O. Institute of Ecology and senior scientist at the Institute of Geography and Regional Studies, University of Klagenfurt. His research focuses on planning and managing protected areas in the context of a changing society. E.C.O., Lakesidepark, B07, 9020 Klagenfurt, Austria. E-mail: jungmeier@ e-c-o.at 